ASIAN AND INTERNATIONAL ORGANIZATIONS 
M.C.W. Pinto - 9789047418306

Downloaded from Brill.com04/26/2023 01:25:02AM via free access 


\section{ASIAN-AFRICAN LEGAL CONSULTATIVE ORGANIZATION}

A survey of activities 2001-2002, including

The work of its Forty-first (Abuja) Session

\section{M.C.W. Pinto*}

Note: The Asian-African Legal Consultative Committee was established on 15 November 1956 to facilitate exchange of views and information on legal matters of common concern to its Members. Its regular Sessions are convened annually, alternately in Asia and Africa. A Session generally takes place in the first half of a calendar year, and is known by the name of the city in which it is held. Consideration of a topic commenced at one Session may continue at subsequent Sessions, as well as inter-sessionally through seminars or expert group meetings; these retain their association with the originating Session. Reports on inter-sessional activities may be discussed at the following Session.

By a resolution adopted at its Special Session in New Delhi on 14 October 1992 (Res. SS 1997/1), the Committee's permanent headquarters was established in New Delhi.

By a resolution adopted at its Fortieth (New Delhi) Session (RES/40/ORG.3 dated 24 June 2001) the Committee decided to change its name to Asian-African Legal Consultative Organization (AALCO).

Member States are represented at Sessions by high level delegations, which may include Chief Justices, Judges, Cabinet Ministers, Attorneys-General, and senior public officials. Sessions are routinely attended by observers from non-Member States, and inter-governmental and non-governmental organizations. The Organization maintains working relationships with the United Nations and its Specialized Agencies and Commissions, as well as with other international organizations, including the International Atomic Energy Agency, UNIDROIT, The Hague Conference on Private International Law, the Commonwealth Secretariat, the Organization of African Unity and the League of Arab States.

The present survey covers the focus of the work of the Organization's Forty-first Session, held at Abuja, Nigeria, 15-19 July 2002, while containing references also

\footnotetext{
* Of the Editorial Board. 
to activities associated with Sessions which were covered in earlier volumes of this Yearbook. The information contained in this survey is taken from Report and Selected Documents of the Forty-first Session published by the Organization.

Information on the activities of AALCO may be obtained from:

The AALCO Secretariat, E-66, Vasant Marg., Vasant Vihar, New Delhi 110057, India E-mail: aalco@del3.vsnl.net.in

\section{MEMBERSHIP AND ORGANIZATION}

There were forty-four Members of the Organization at the time of its Forty-first Session, held at Abuja, Nigeria, from 15-19 July 2002: Bahrain, Bangladesh, China, Cyprus, Egypt, Gambia, Ghana, India, Indonesia, Iran, Iraq, Japan, Jordan, Kenya, Democratic People's Republic of Korea, Republic of Korea, Kuwait, Lebanon, Libya, Malaysia, Mauritius, Mongolia, Myanmar, Nepal, Nigeria, Oman, Pakistan, Palestine, Philippines, Qatar, Saudi Arabia, Senegal, Sierra Leone, Singapore, Somalia, Sri Lanka, Sudan, Syria, Tanzania, Thailand, Turkey, Uganda, United Arab Emirates, and Yemen. Botswana is an Associate Member.

\section{INTER-SESSIONAL MEETINGS AND OTHER ACTIVITIES}

A Meeting of Legal Advisers of AALCO Member States convened at New York on 20 November 2001, presided over by Dr. P. Sreenivasa Rao (India). The meeting focused on the work of the Preparatory Commission for the International Criminal Court, and on the topics of terrorism and corruption (Report, p. 7).

A Seminar on Human Rights and Combating Terrorism was held at Abuja on 15 July 2002 in conjunction with the Forty-first Session, in collaboration with the Office of the High Commission to Human Rights, the UN High Commission for Refugees and the International Organization for Migration (Report, pp. 623-643).

The Organization is to strengthen its Centre for Research and Training, and to establish a new Centre for Energy and Environmental Law (Report, pp. 9, 14-15).

\section{OFFICERS OF THE FORTY-FIRST (ABUJA) SESSION}

The Forty-first Session of the Organization elected as President Senator the Hon. Kanu G. Agabi, SAN, the Attorney-General and Minister of Justice of Nigeria, and H.E. Professor Dr. Yusril Ihza Mahendra, Minister of Justice and Human Rights of Indonesia, as Vice-President. Mrs. Ernestine Kamuhabwa, Minister Plenipotentiary at the High Commission for Tanzania in New Delhi, was elected Rapporteur of the Special Meeting on Human Rights and Combating Terrorism.

\section{ORGANIZATION OF THE SESSION}

Ambassador Dr. Wafik Zaher Kamil (Egypt), the Secretary-General of the Organization, was responsible for the organization of the Session. He was assisted by Dr. Ahmed Jassim Al-Gaatri (Qatar), Dr. Ali Reza Deihim (Iran), and Mrs. Toshiko Shimizu (Japan), Deputy Secretaries-General, by Dr. Li Zhenhua (China), Assistant Secretary-General, and by the AALCO Staff. 


\section{SUBJECTS DEALT WITH BY THE ORGANIZATION}

The Organization considered and adopted resolutions on the subjects listed below, the order of their discussion having been determined at the commencement of the Session. The references next to each subject are to the pages of the Report of the Forty-first Session issued by the Secretariat** The Report on each Session will, from 2003, be contained in a volume entitled Yearbook of the Asian-African Legal Consultative Organization..

\section{Questions under consideration by the International Law Commission (Report, pp. 17-109)}

The Secretariat's report on the work of the Commission at its Fifty-third Session (2001) (Report, p. 17-109) focussed on the Commission's work on six topics: State responsibility; International liability for injurious consequences arising out of acts not prohibited by international law; Reservations to treaties; Diplomatic protection; Unilateral acts of States, and Jurisdictional immunities of States and their property. Of particular interest from an Asian perspective are (1) Jurisdictional immunities of States and their property, a topic of the International Law Commission which, on the initiative of Japan at the Cairo Session (2000), was placed on AALCO's own agenda (Report, pages 101-149); and (2) International liability for injurious consequences arising out of acts not prohibited by international law, a topic for which the Commission's Special Rapporteur is Dr. P. Sreenivasa Rao of India (Report, pp. 63-80).

A list of the Members of the International Law Commission elected by the General Assembly on 7 November 2001, who will hold office 2002-2006, is at pages 108-9 of the Report. Of the 34 Members of the Commission, eight are from Asia: Husain Al-Baharna (Bahrain), Ali Mohsen Fetais Al-Marri (Qatar), Choung Il Chee (Rep. of Korea), Riad Daoudi (Syrian Arab Republic), Djamchid Momtaz (Islamic Republic of Iran), Pemmaraju Sreenivasa Rao (India), Xue Hanqin (China), and Chusei Yamada (Japan). This election itself was noteworthy in that, for the first time since the establishment of the Commission on 21 November 1947, the General Assembly elected two women to membership: Xue Hanqin (China), and Paula Escarameia (Portugal).

\section{Matters referred to the Committee by Member States}

1. Law of the Sea (Report, pp. 179-216)

The Session reviewed the work of the institutions created for giving effect to the provisions of the 1982 UN Convention on the Law of the Sea, and heard a wideranging statement by the President of the International Tribunal for the Law of the Sea (ITLOS), Judge P.C. Rao, on dispute settlement mechanisms provided for under the Convention (pp. 180-185). The Report contains a Secretariat study of the work of the institutions established by the Convention, and brief notices of the cases that had, until then, been decided by ITLOS: MV Saiga No. 1, MV Saiga No. 2, Southern Bluefin Tuna cases, Camouco case, Monte Confurco case, Swordfish stocks case, Grand Prince case, Chaisiri Reefer 2 case, and the MOX Plant case (Report, pp. 204-9). 
2. Status and treatment of Refugees (Report, pages 348-360)

The Organization completed its work on a consolidated text of the Revised Bangkok Principles (for the original text see Asian YIL, Vol 7 (1997), pp. 381-7) taking into account Member States' comments. The Revised Consolidated text of the Bangkok Principles on the Status and Treatment of Refugees adopted by the Organization at its Fortieth (New Delhi) Session on 24 June 2001 was reproduced in this Yearbook, Vol. 10 (2002).

The Revised Bangkok Principles are regarded as "declaratory and non-binding", but should "guide and inform" Members of AALCO (Report, p. 360). This Report reproduces written comments by the Government of Malaysia (Report, pp. 357-9), and a Secretariat study on (1) recent initiatives by the UN High Commissioner for Refugees, and (2) suggestions for AALCO's future work programme on the topic (Report, pp. 361-8).

\section{Human Rights in Islam (Report, pp. 217-223)}

Proposed by Saudi Arabia for inclusion in the Organization's agenda at its Fortieth Session, the topic was taken up for consideration at its Forty-first Session. A Secretariat summary of the customary background note, furnished by Saudi Arabia, lists the following as having been elaborated therein: Right to Respect, Man's Right to Life, Man's Right to Security, Right to Property, Man's Right to Safeguard His Dignity, Man's Right to Education, Woman's Rights and her Status in Islam, and Child's Rights in Islam.

As to the main issue for discussion in connection with the topic, the Secretariat summary quotes from the paper presented by the Saudi Ministry of Justice:

"[H]uman rights in Islam are based on divinity of the source and necessary commitment to abiding by the religious rules of which they form a part, and no ruler or authority is allowed to play with them or try to amend or abolish them, and that is also our conviction ..."

The following additional excerpts from the paper are quoted:

"Let me cite a single example which is being raised by those who don't believe in our undisputed and unquestionable matters. These opponents of Shari'ah rules think that in establishing punishment for theft, like cutting off body parts, there is cruelty and insult to the dignity of a human being. We inform them that these rules are not laid down by a person or a ruler, but they are revealed by Allah the Almighty in the Holy Qur'an. He said, 'As for the male thief and the female thief, cut off their hands as a recompense for that which they committed'. Muslims are unanimous since the beginning of Islam till the present time on the truth and implementation of this rule ... So if, as a deterrent to crime, the Islamic Shari'ah pronounces the punishment of cutting off hands, it is not cruelty. This Shari'ah is famous for its compassion ... [but] mercy will not be shown to one who does not show mercy to others." (Report, pp. 217-8) 
Several delegations welcomed Saudi Arabia's initiative in placing the topic before AALCO. However, discussion of the topic was postponed.

4. Deportation of Palestinians and other Israeli practices, among them the massive immigration and settlement of Jews in occupied territories in violation of international law, particularly the Fourth Geneva Convention of 1949 (Report, pp. 369-412)

A Secretariat summary of international action on the subject (Report, pp. 390-412) covers developments since the Fortieth Session of AALCO including the JordanianEgyptian Peace Proposal (April 2001) and the proposal of Saudi Arabia's Crown Prince Abdullah (March 2002), as well as action by the Security Council and General Assembly of the United Nations, the Organisation of the Islamic Conference, the Arab League and the Non-aligned Movement.

\section{Legal protection of Migrant Workers (Report, pp. 413-452)}

The extensive discussion of this topic which took place at a Special Meeting on Some Legal Aspects of Migration, held on 22 June 2001 during the Fortieth Session of the Committee, was summarized in the Report on that Session at pp. 598645. Subsequent developments are summarised in the Report on the Forty-first Session at pp. 415-420; 449-452. A Draft Model Agreement between States of Origin and States of Destination prepared by the Secretariat has been circulated to the Members of AALCO for comment.

\section{Extra-territorial application of national legislation: sanctions imposed against} third parties (Report, pp. 150-178)

Members re-affirmed views expressed at the Organization's Thirty-sixth, Thirtyseventh, Thirty-eighth, Thirty-ninth, and Fortieth Sessions that the extra-territorial imposition of national laws violated State sovereignty and interfered with the legitimate economic interests of States. A Secretariat study on the subject and the Secretariat's report on discussion of related issues at the Fifty-sixth (2001) Session of the United Nations General Assembly, are at pp. 155-178.

7. Jurisdictional immunities of States and their property (Report, pp. 110-149) Referred to the Organization at its Cairo Session (2000) by the Delegation of Japan, consideration of this topic takes account of the work of the International Law Commission, and discussion of it at meetings of the Sixth Committee of the UN General Assembly. With a view to collating the views of AALCC's Members States, the Secretary-General by his letter dated 3 July 2000, invited them to transmit to it national legislation, court decisions, and other relevant materials on the topic. The Report reproduces responses from Japan (pp. 134-7) and Myanmar (pp. 138-149).

\section{International terrorism (Report, pp. 273-301)}

Referred to the Organization by the Government of India, the topic was placed on the agenda of its Fortieth Session for the first time, and taken up for discussion at its Forty-first Session. Summing up the views expressed at that Session, the 
President emphasized that military means of fighting terrorism were not the only ones. Other means of resolving the problem, such as the diplomatic and political, should also be used, he said. It was also essential to investigate and determine the root causes of terrorism. The struggle for liberation from foreign occupation should, in his opinion, be distinguished from terrorism.

A Secretariat study of the topic (Report, pp. 287-301) summarizes deliberations at the UN Ad hoc Committee charged with elaborating draft Conventions on the suppression of terrorist bombings (established at the Fifty-second Session (1997) of the General Assembly), the suppression of acts of nuclear terrorism, and suppression of financing terrorism (adopted at the Fifty-fourth Session (1999) of the General Assembly); and covers extension of the Committee's mandate at the Assembly's Fifty-fourth Session, to the drafting of a comprehensive Convention on international terrorism, based on the draft by India circulated during the Assembly's Fiftyfirst Session in 1996.

A report by Ms. Ernestine Kamuhabwa (Tanzania) on the Special Meeting on Human Rights and Combating Terrorism, held in conjunction with the Organization's Forty-first Session (17 July 2002), is at pp. 623-646. The report includes summaries of statements on the topic by representatives of the High Commissioner for Human Rights, of the International Organization for Migration, and other members of a Panel of Experts.

\section{Establishing co-operation against trafficking in women and children (Report, pp. 453-508)}

Referred to the Organization by the Government of Indonesia, the topic was placed on the agenda of its Fortieth Session for the first time and taken up for discussion at the Forty-first Session. A Secretariat study of the topic covers the $U N$ Convention against Transnational Organized Crime adopted at the Fifty-fifth Session of the UN General Assembly on 15 November 2000, and its Protocols (Protocol to Prevent, Suppress and Punish Trafficking in Persons, and Protocol against Smuggling of Migrants by Land, Air and Sea), as well as the work of the International Organization for Migration and the Office of the High Commissioner for Human Rights.

\section{Matters of common concern having legal implications}

1. United Nations Diplomatic Conference of Plenipotentiaries on the establishment of an International Criminal Court (Rome, 15 June-17 July 1998) (Report, pp. 302-347)

The Secretariat's study (Report, pp. 320-347) covers the work of the Preparatory Commission at its Eighth, Ninth, and Tenth Sessions, and the entry into force of the Convention on 1 July 2002, noting that, among the 139 States that had signed the Rome Statute of the ICC by that date, were the following Members of AALCO: Bahrain, Bangladesh, Botswana, Cyprus, Egypt, Gambia, Iran, Jordan, Kenya, Kuwait, Mauritius, Mongolia, Nigeria, Oman, Philippines, Rep. of Korea, Senegal, Sierra Leone, Sudan, Syria, Thailand, Uganda, United Arab Emirates, and Tanzania. 
2. United Nations Conference on Environment and Development (Report, pp. 225-272)

The Report contains the Secretariat's review of the work of the Conference of the Parties to the UN Convention on Climate Change at its Seventh Session (Marrakech, 29 October-10 November 2001), which focuses on implementation of States' responsibilities regarding (1) capacity building, (2) technology transfer, and (3) funding, as well as the need to bring the Kyoto Protocol into force as soon as possible and implement its procedures and mechanisms aimed at securing compliance with its provisions. The Report also covers the work of subsidiary bodies established under the UN Convention on Biological Diversity, in anticipation of the sixth meeting of the Conference of the Parties, scheduled to take place at The Hague, 8-19 April 2002; and of the Fifth Session of the Conference of the Parties, to the Convention to Combat Desertification, 1-13 October 2001. Preparations for the ten-year review of action taken since the 1992 UN Conference on Environment and Development, at a meeting designated by the UN as the "World Summit on Sustainable Development", are reported at pp. 263-272.

\section{An Effective International Legal Instrument against Corruption (Report, pp. 509-533)}

Placed on the Organization's agenda in response to a proposal by its SecretaryGeneral, the item reflects concerns similar to those of the UN General Assembly in establishing, on 4 December 2001 by resolution 55/61, an Ad hoc Committee to commence negotiations for the conclusion of an effective legal instrument against corruption. A study by the Secretariat summarizes the work of the First Session of the UN's Ad hoc Committee held in Vienna 21 January-1 February 2002, attended by several AALCO Members, including China, India, Indonesia, Iran, Iraq, Japan, Jordan, Kuwait, Lebanon, Malaysia, Oman, Pakistan, Philippines, Qatar, Rep. of Korea, Saudi Arabia, Syria, Thailand, United Arab Emirates, and Yemen. Also covered are discussions taking place in a parallel inter-governmental group, the Global Forum, the first meeting of which convened in Washington, DC, 24-26 February 1999, and adopted "Guiding Principles for fighting corruption and safeguarding integrity among Justice and Security Officials" (Report, pp. 522-533).

\section{International Trade Law Matters (Report, pp. 534-622)}

The Secretariat continued its regular review of the work of international organizations in the field of international trade law. The review covers the work of the United Nations Commission on International Trade Law (UNCITRAL), the United Nations Conference on Trade and Development (UNCTAD) and its Commissions, and the United Nations Industrial Development Organization (UNIDO); as well as of the International Institute for the Unification of Private Law UNIDROIT), the Hague Conference on Private International Law, and the World Trade Organization. A Secretariat study entitled "WTO as a Framework Agreement and Code of Conduct for World Trade" is at pp. 597-622. 